Supporting Information

for

\title{
Readily Available Fluorescent Probe for Carbon Monoxide Imaging in Living Cells
}

\author{
Weiyong Feng, Dandan Liu, Shumin Feng, and Guoqiang Feng* \\ Key Laboratory of Pesticide and Chemical Biology of Ministry of Education, College of Chemistry, Central China \\ Normal University, 152 Luoyu Road, Wuhan 430079, P. R. China. \\ *Corresponding author. E-mail: gf256@mail.ccnu.edu.cn (G.Feng).
}

Table of contents

1. Structure characterizations for FL-CO-1 and FL-CO-2 ..........Page S2-S4

2. Additional Data............................................Page S5-S11 
1. Structure Characterizations for FL-CO-1 and FL-CO-2.

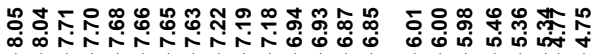

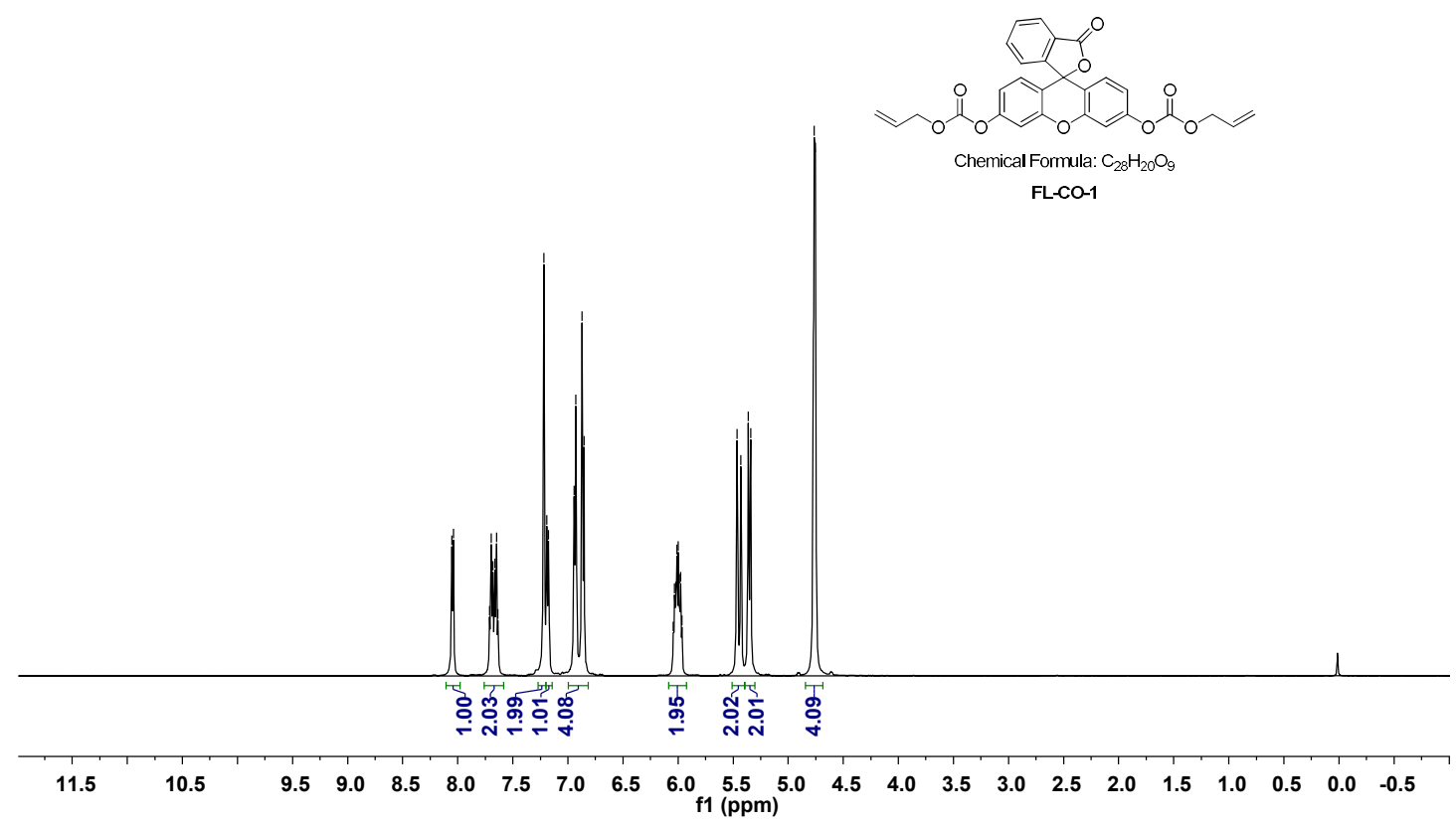

${ }^{1} \mathrm{H}$ NMR spectrum of FL-CO-1 in $\mathrm{CDCl}_{3}$.
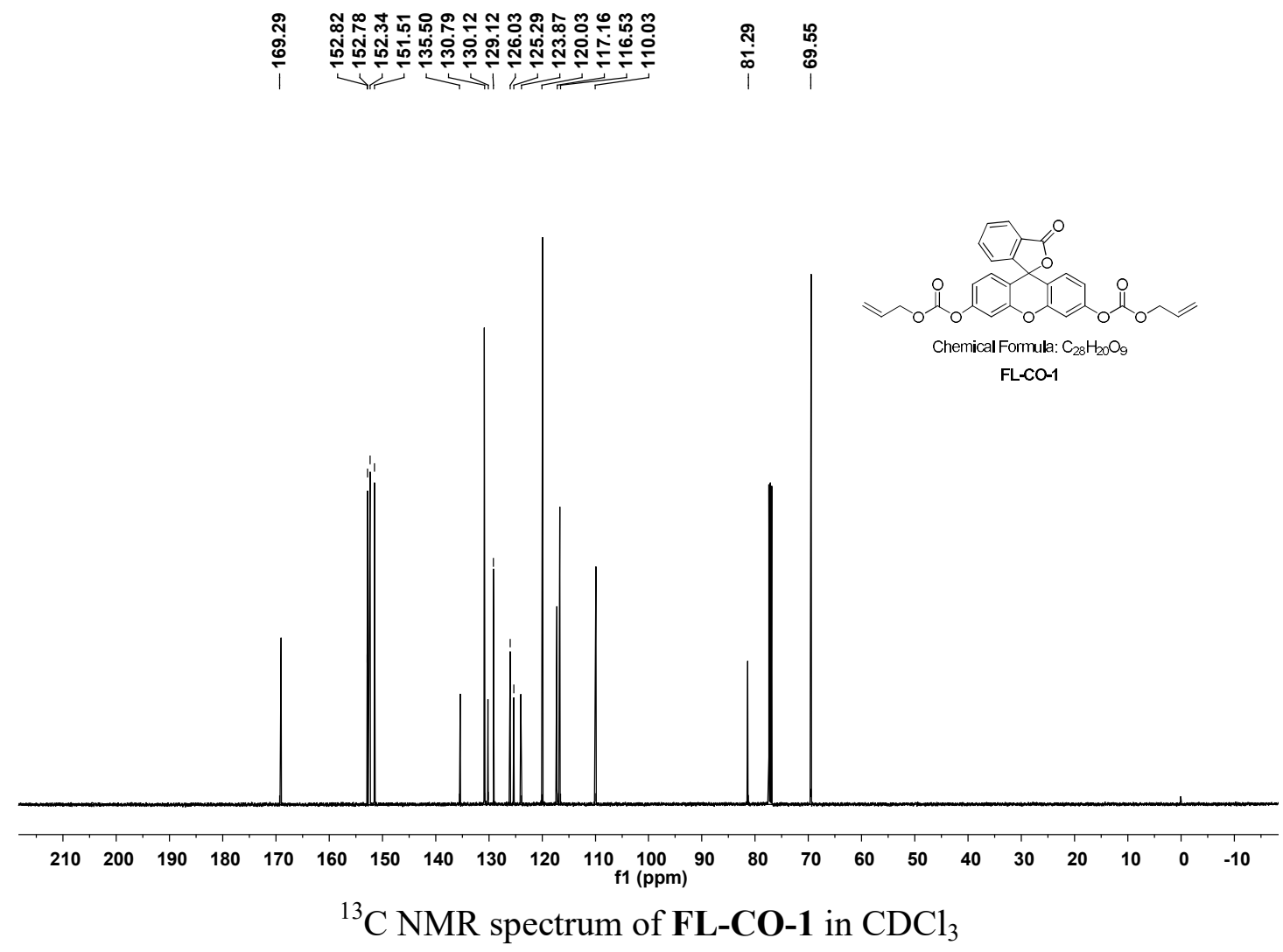


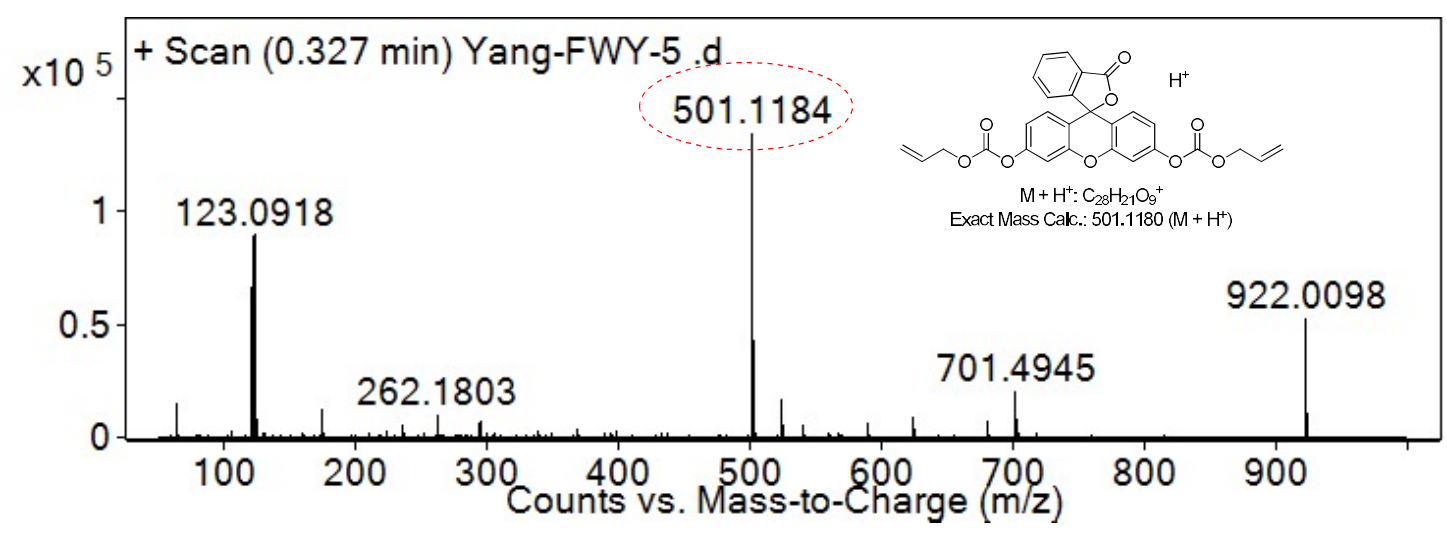

HR-MS spectrum of FL-CO-1

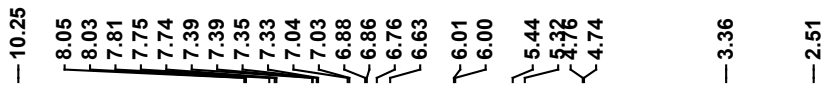

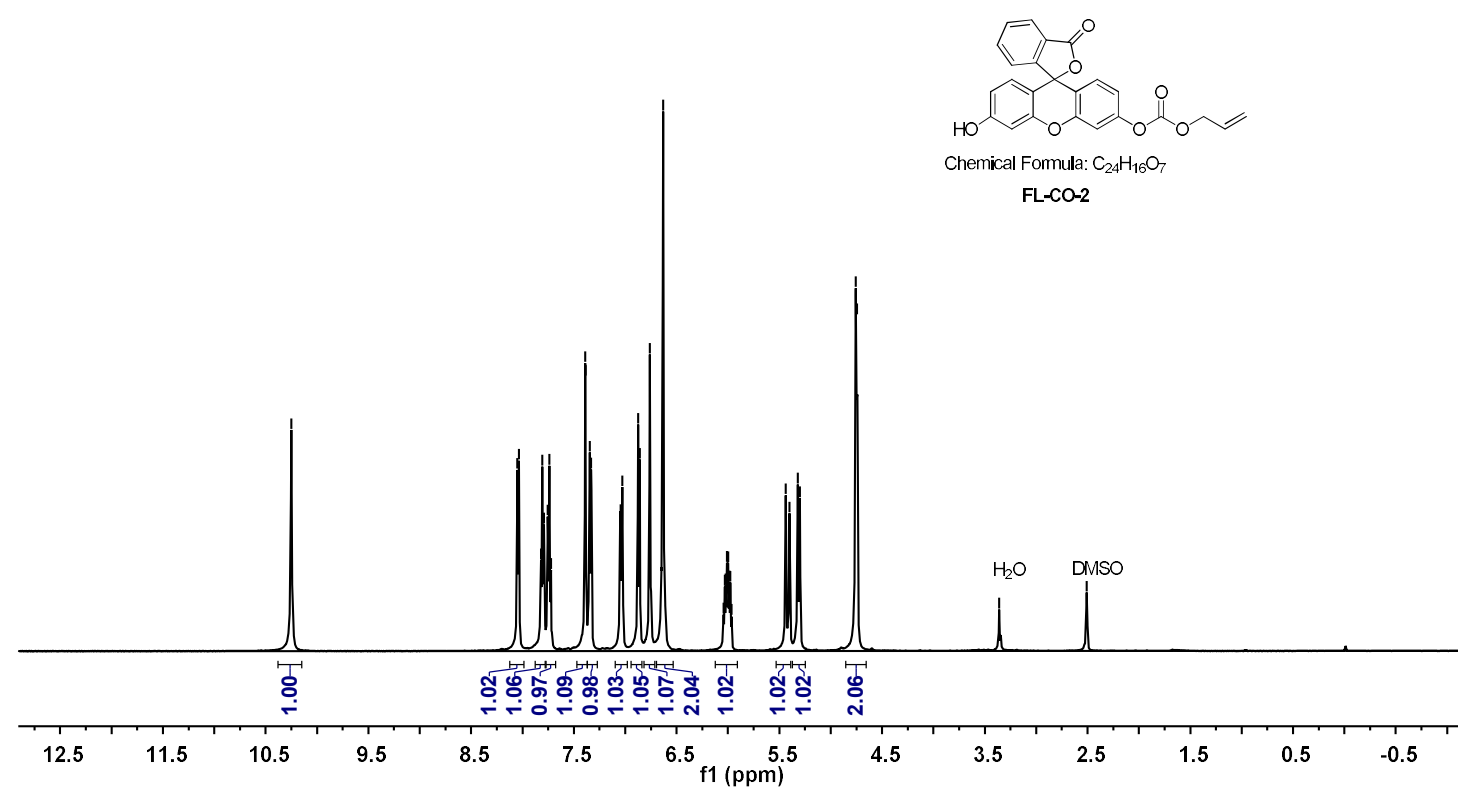

${ }^{1} \mathrm{H}$ NMR spectrum of FL-CO-2 in $d_{6}$-DMSO 

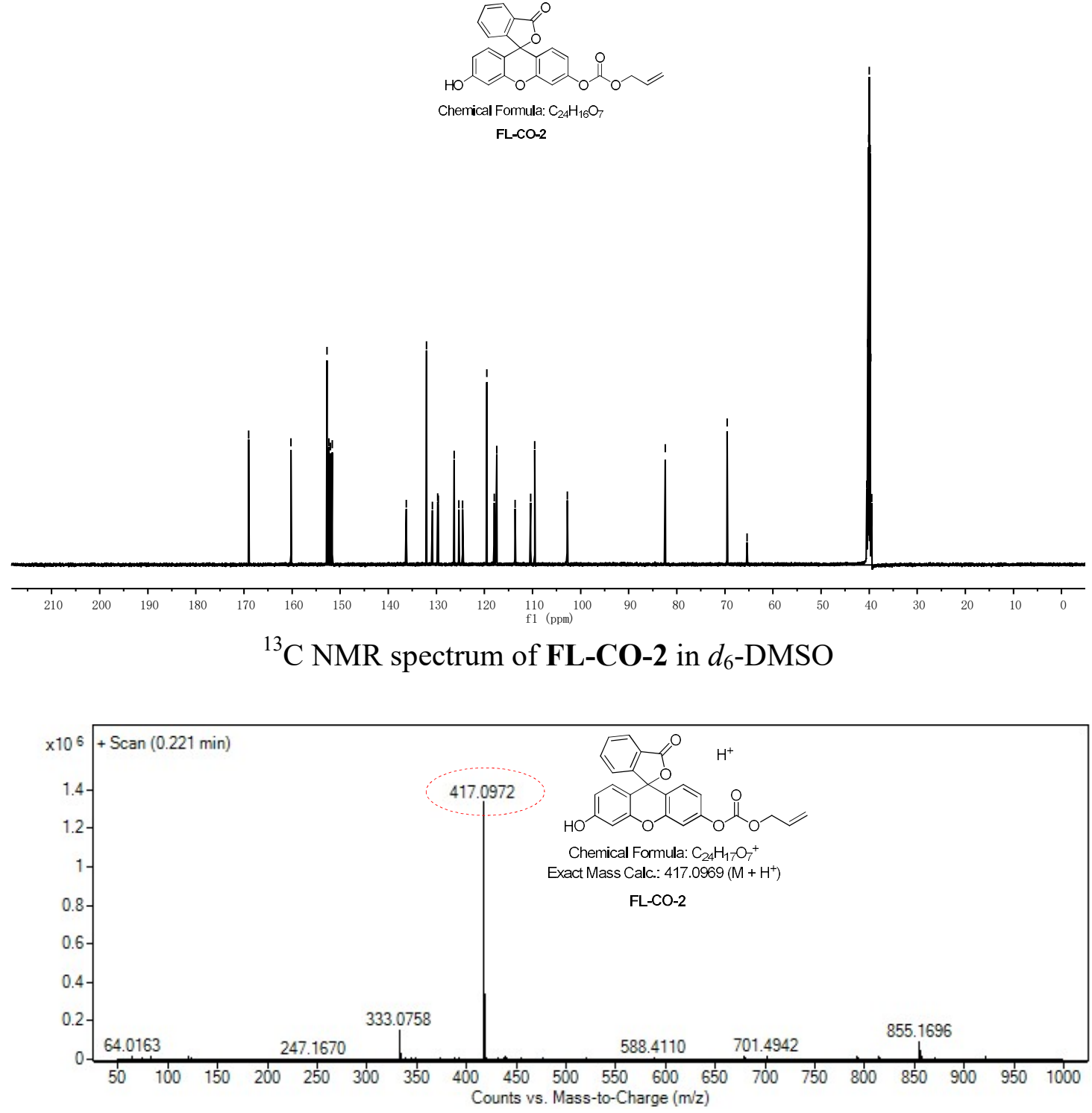

HR-MS spectrum of FL-CO-2 


\section{Additional Data}
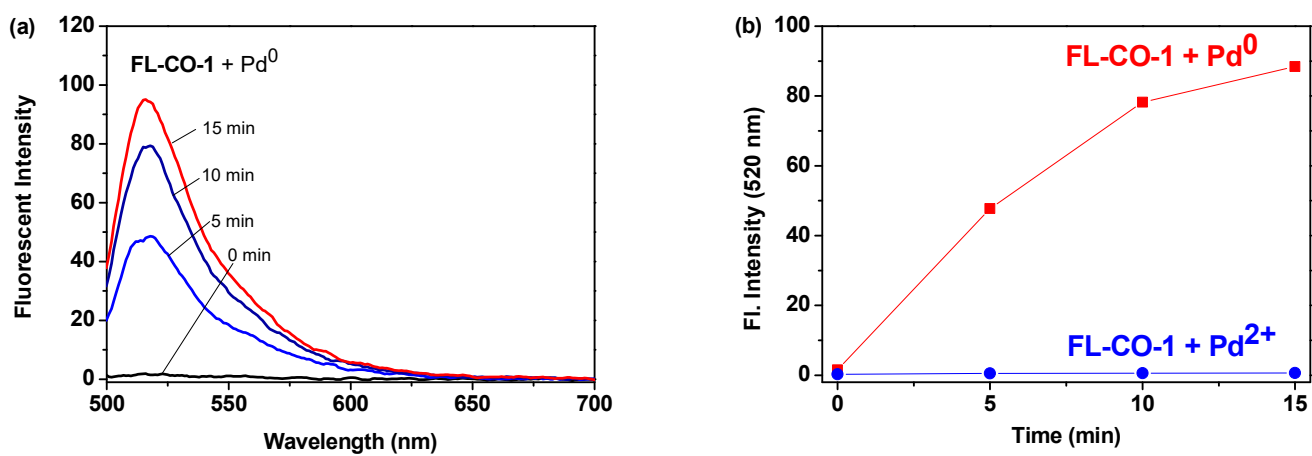

Figure S1. (a) Fluorescent spectra changes of probe FL-CO-1 $(5 \mu \mathrm{M})$ upon addition of $\mathrm{Pd}\left(\mathrm{PPh}_{3}\right)_{4}(5 \mu \mathrm{M})$ in PBS buffer $(10 \mathrm{mM}, \mathrm{pH} 7.4)$ at $37^{\circ} \mathrm{C}$. (b) Time-dependent fluorescent intensity changes of probe FL-CO-1 $(5 \mu \mathrm{M})$ at $520 \mathrm{~nm}$ upon addition of $\mathrm{Pd}\left(\mathrm{PPh}_{3}\right)_{4}(5 \mu \mathrm{M}, \mathbf{\square})$ and $\mathrm{PdCl}_{2}(5 \mu \mathrm{M}, \bullet)$ in PBS buffer $(10 \mathrm{mM}, \mathrm{pH} 7.4)$ at $37{ }^{\circ} \mathrm{C}$. $\lambda_{\mathrm{ex}}=490 \mathrm{~nm}$, slit width: $d_{\mathrm{ex}}=d_{\mathrm{em}}=2.5 \mathrm{~nm}$.

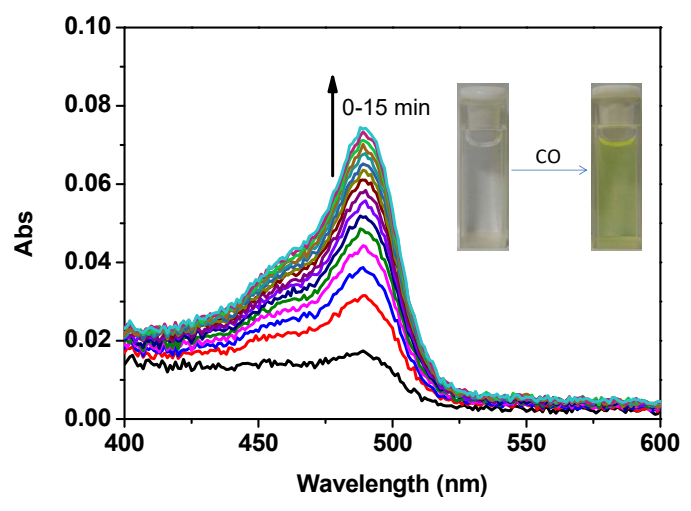

Figure S2. UV-Vis spectra changes of the probe system $(5 \mu \mathrm{M}$ FL-CO-1 $+5 \mu \mathrm{M}$ $\left.\mathrm{PdCl}_{2}\right)$ against time $(0-15 \mathrm{~min})$ upon addition of CORM-3 $(50 \mu \mathrm{M})$ in PBS buffer $(10$ $\mathrm{mM}, \mathrm{pH} 7.4$, with $0.5 \% \mathrm{DMSO}, \mathrm{v} / \mathrm{v}$ ) at $37{ }^{\circ} \mathrm{C}$. Insert: the color changes under room light. 

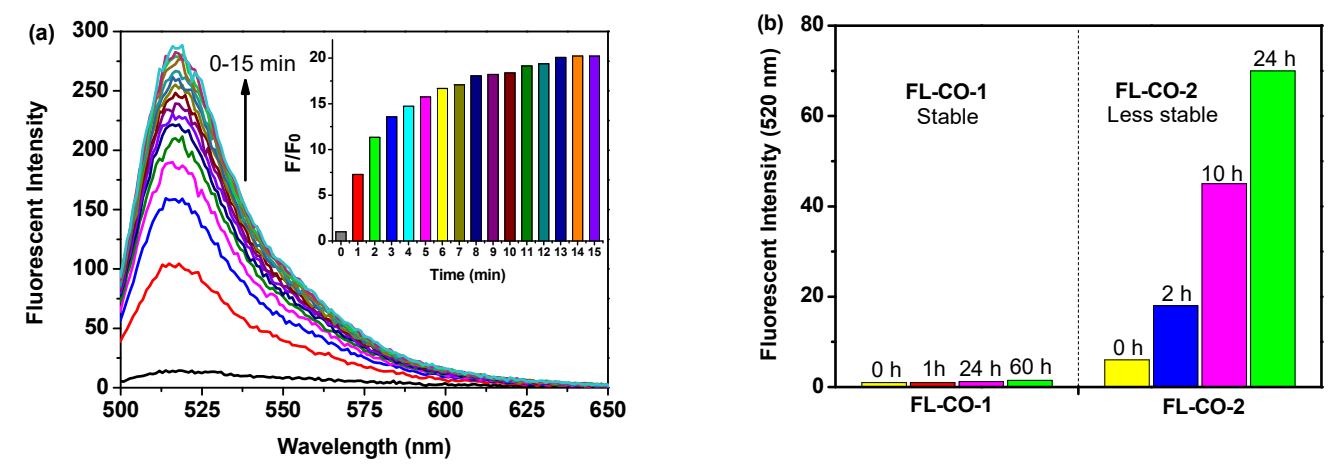

Figure S3. (a) Fluorescence spectra changes of FL-CO-2 $(5 \mu \mathrm{M})+\operatorname{PdCl}_{2}(5 \mu \mathrm{M})$ upon addition of CORM-3 $(50 \mu \mathrm{M})$ in PBS buffer $(10 \mathrm{mM}$, pH 7.4, with 0.5\% DMSO, $\mathrm{v} / \mathrm{v})$ at $37^{\circ} \mathrm{C}$. The spectra were recorded every $1 \mathrm{~min}$. Insert: fluorescent intensity ratio $\left(\mathrm{F} / \mathrm{F}_{0}\right)$ changes at $520 \mathrm{~nm}$ as a function of time. (b) Fluorescent stability of the stock solutions of FL-CO-1 and FL-CO-2 by measuring their fluorescent intensities at $520 \mathrm{~nm}$ after they were kept at the indicated time under the same conditions. The data were measured in PBS buffer $\left(10 \mathrm{mM}, \mathrm{pH} 7.4\right.$, with $0.5 \%$ DMSO, v/v) at $37{ }^{\circ} \mathrm{C}$ by diluting the stock solution to $5 \mu \mathrm{M}$ before measurement. For all measurements, $\lambda_{\mathrm{ex}}$ $=490 \mathrm{~nm}$, slit width: $d_{\mathrm{ex}}=d_{\mathrm{em}}=2.5 \mathrm{~nm}$.
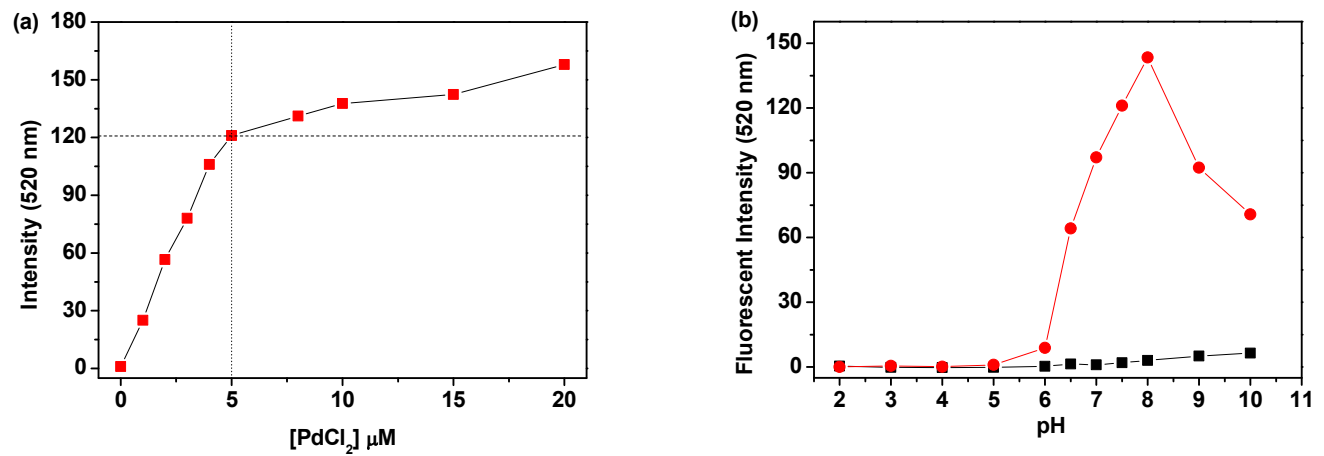

Figure S4. (a) Fluorescence intensity changes of FL-CO-1 $(5 \mu \mathrm{M})$ for CORM-3 (50 $\mu \mathrm{M})$ with different concentrations of $\mathrm{PdCl}_{2}$ in PBS buffer $(10 \mathrm{mM}, \mathrm{pH} 7.4,0.5 \%$ DMSO, v/v) at $37^{\circ} \mathrm{C}$. Each data was recorded 15 min after mixing. $\lambda_{\text {ex }}=490 \mathrm{~nm}$, slit width: $d_{\mathrm{ex}}=d_{\mathrm{em}}=2.5 \mathrm{~nm}$. (b) Fluorescence responses of the probe system ( $5 \mu \mathrm{M}$ FL-CO-1 $\left.+5 \mu \mathrm{M} \mathrm{PdCl}_{2}\right)$ in the absence and presence of CORM-3 $(50 \mu \mathrm{M})$ under different pHs. All experiment was performed in PBS buffer $(10 \mathrm{mM}$, with $0.5 \%$ 
DMSO, v/v) at $37^{\circ} \mathrm{C}$. Each spectrum was obtained 15 min after mixing. $\lambda_{\mathrm{ex}}=462 \mathrm{~nm}$, $\lambda_{\mathrm{ex}}=490 \mathrm{~nm}$, slit width: $d_{\mathrm{ex}}=d_{\mathrm{em}}=2.5 \mathrm{~nm}$.

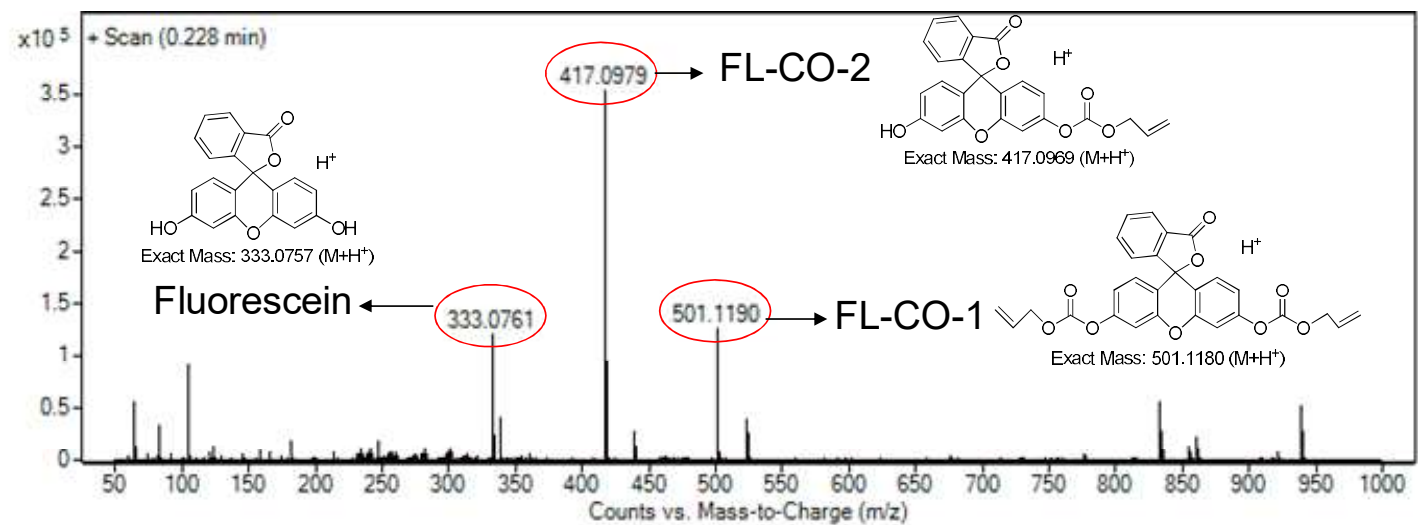

Figure S5. Mass spectrum of the mixture of the probe system $(5 \mu \mathrm{M}$ FL-CO-1 +5 $\mu \mathrm{M} \mathrm{PdCl} 2)$ after addition of CORM-3 $(50 \mu \mathrm{M})$ in PBS buffer $(10 \mathrm{mM}, \mathrm{pH} 7.4$, with $0.5 \%$ DMSO). The spectrum was taken 5 min after mixing. The peak at $\mathrm{m} / \mathrm{z}=$ 333.0761 $\left[\mathrm{M}+\mathrm{H}^{+}\right]$and $417.0979\left[\mathrm{M}+\mathrm{H}^{+}\right]$can be characterized the produced fluorescein (Calc. 333.0757) and FL-CO-2 (Calc. 417.0969), respectively. The peak at $m / z=501.1190\left[\mathrm{M}+\mathrm{H}^{+}\right]$represent the unreacted FL-CO-1 (Calc. 501.1180).

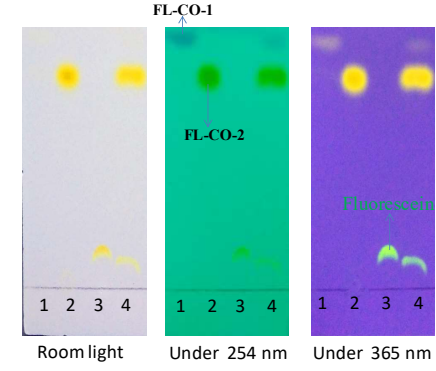

(a) Reaction time: 5 min

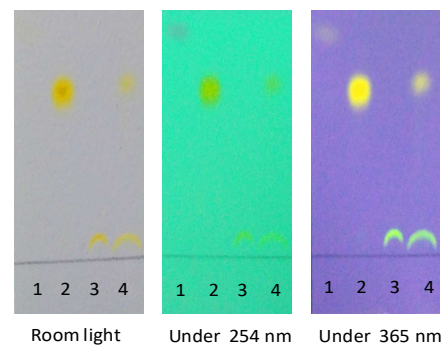

(b) Reaction time: 20 min

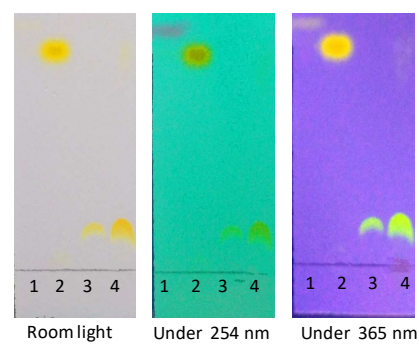

(c) Reaction time: $180 \mathrm{~min}$

Figure S6. The reaction of the probe system $\left(5 \mu \mathrm{M}\right.$ FL-CO-1 $\left.+5 \mu \mathrm{M} \mathrm{PdCl}_{2}\right)$ after addition of CORM-3 $(50 \mu \mathrm{M})$ in PBS buffer $(10 \mathrm{mM}$, pH 7.4, with 0.5\% DMSO) was monitored by TLC at (a) $5 \mathrm{~min}$, (b) $20 \mathrm{~min}$ and (c) $180 \mathrm{~min}$. Numbers $1-4$ in the TLC plates represent: 1. FL-CO-1, 2. reference sample of FL-CO-2, 3. reference sample of fluorescein, 4. sample from the reaction mixture. 

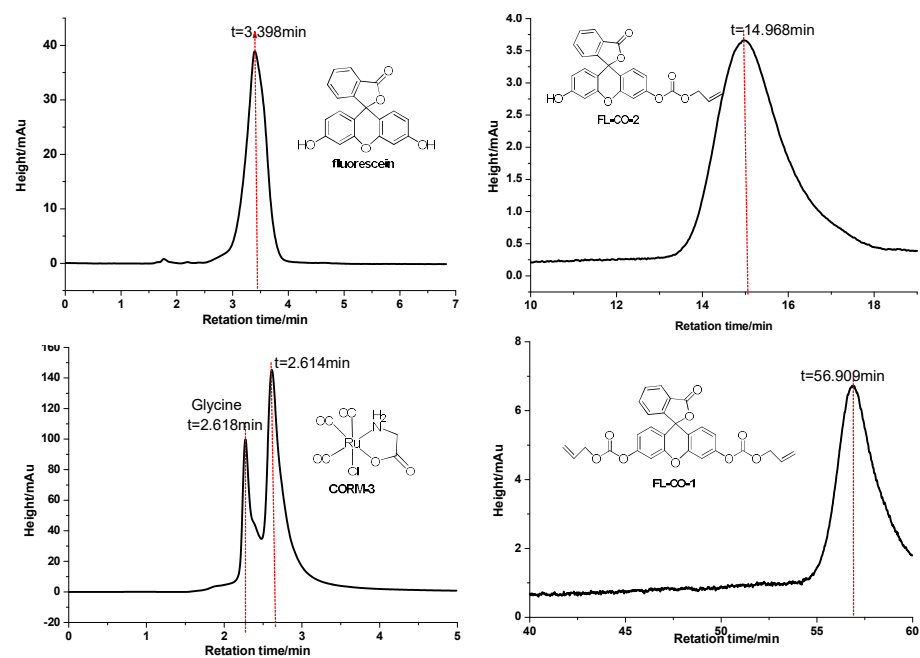

(a) HPLC traces of the reference samples

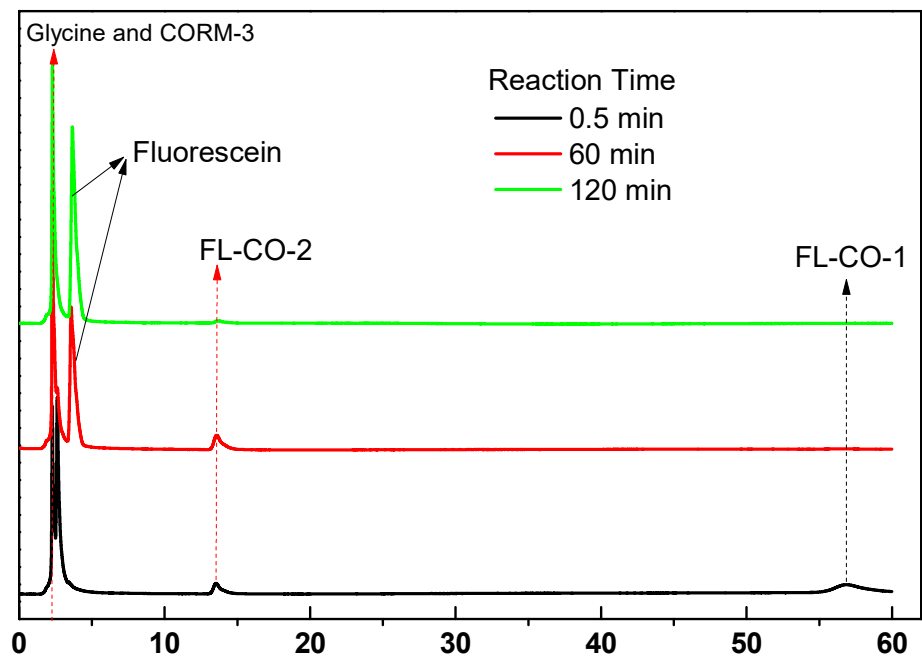

(b) HPLC traces of the reaction of the probe system $\left(5 \mu \mathrm{M}\right.$ FL-CO-1 $\left.+5 \mu \mathrm{M} \mathrm{PdCl}_{2}\right)$ with CORM-3 $(50 \mu \mathrm{M})$ in PBS buffer (10 mM, pH 7.4, with 0.5\% DMSO) at different times

Figure S7. HPLC analyses. Column: Agilent ZORBAX SB-C18, 150×4.6 mm, 5 um; eluent: $\mathrm{CH}_{3} \mathrm{OH}-\mathrm{H}_{2} \mathrm{O} \quad 65: 35$, v/v; flow rate: $1.2 \mathrm{~mL} / \mathrm{min}$, temperature: $40{ }^{\circ} \mathrm{C}$, monitored at $254 \mathrm{~nm}$.

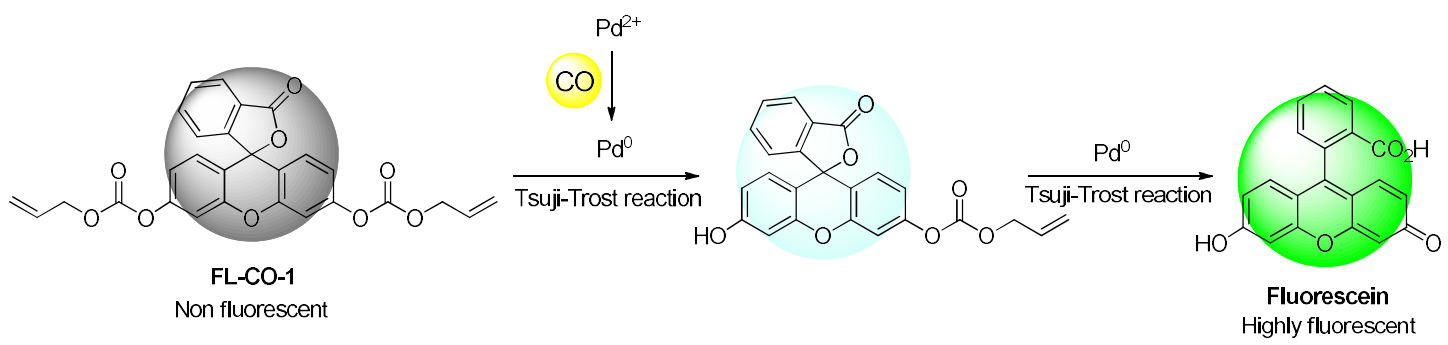

Scheme S1 The proposed sensing mechanism for CO detection 


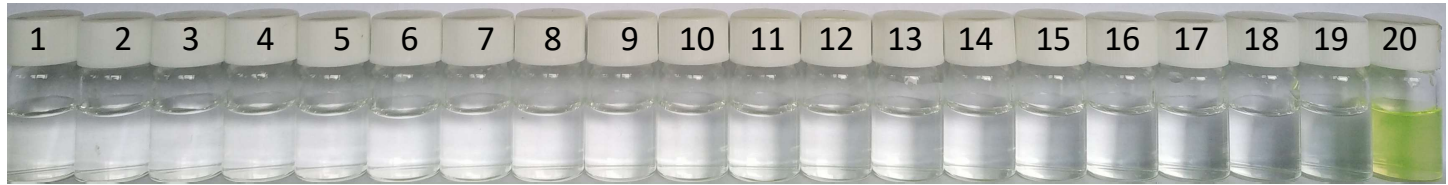

(a) Under visible light

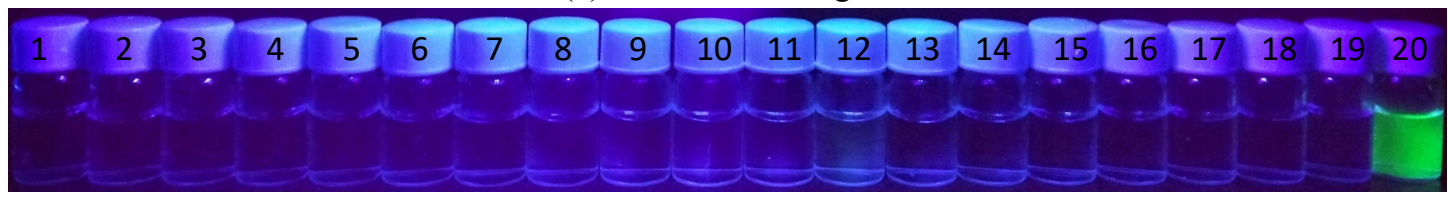

(b) Under a light of $365 \mathrm{~nm}$

Figure S8. (a) Color and (b) emission color changes of the probe system (5 $\mu \mathrm{M}$ FL-CO-1 $\left.+5 \mu \mathrm{M} \mathrm{PdCl}_{2}\right)$ in PBS buffer $(10 \mathrm{mM}$, pH 7.4, with $0.5 \% \mathrm{DMSO}$, v/v) with $100 \mu \mathrm{M}$ of different analytes (1, none, $2 . \mathrm{F}^{-}, 3 . \mathrm{Cl}^{-}, 4 . \mathrm{Br}^{-}, 5 . \mathrm{I}^{-}, 6 . \mathrm{N}_{3}{ }^{-}, 7 . \mathrm{SO}_{4}{ }^{2-}, 8$. $\mathrm{AcO}^{-}, 9 . \mathrm{HCO}_{3}^{-}, 10 . \mathrm{HSO}_{3}^{-}, 11 . \mathrm{HS}^{-}, 12$. a mixure of Ala, Leu, Trp, Gly, Ile, and Lys, 13. a mixure of Cys, Hcy, and $\mathrm{GSH}, 14 . \mathrm{ClO}^{-}, 15 . \mathrm{H}_{2} \mathrm{O}_{2}, 16 . \mathrm{NO}, 17 . \mathrm{NO}_{2}^{-}, 18$. ${ }^{t} \mathrm{BuOO}^{\circ}, 19{ }^{\circ} \mathrm{OH}, 20 . \mathrm{CORM}-3$. The emission color change was taken under a portable $365 \mathrm{~nm}$ lamp.
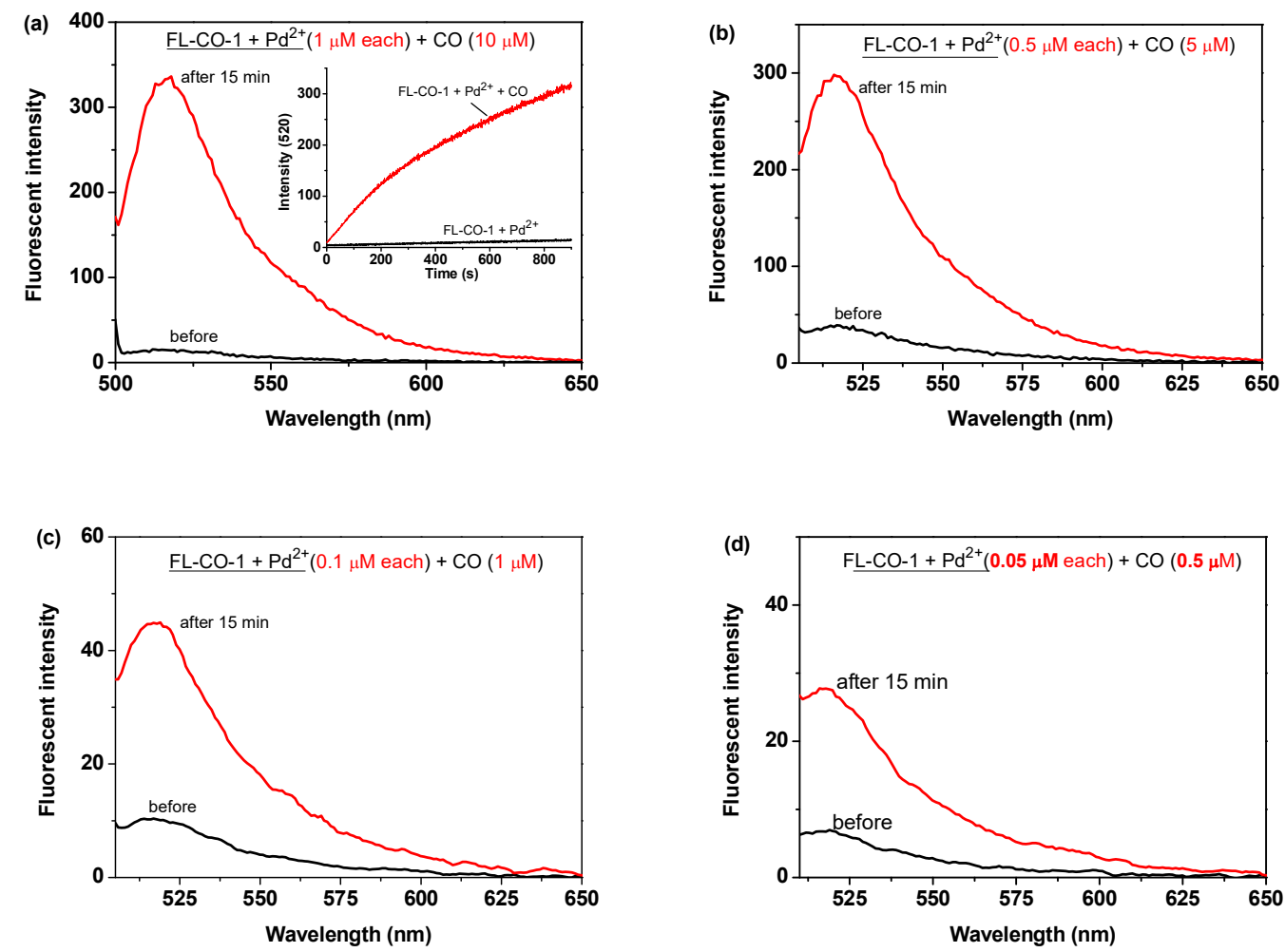

Figure S9. Fluorescent spectra changes of the probe system upon addition of 10 equiv. of CORM-3 in PBS buffer $(10 \mathrm{mM}, \mathrm{pH}=7.4$, with $0.5 \% \mathrm{DMSO}, \mathrm{v} / \mathrm{v})$ at $37^{\circ} \mathrm{C}$. (a) The probe system was used FL-CO-1 $+\mathrm{PdCl}_{2}(1 \mu \mathrm{M}$ each $)$, and CORM-3 $(10 \mu \mathrm{M})$ was 
added. $\lambda_{\mathrm{ex}}=490 \mathrm{~nm}$, slit width: $d_{\mathrm{ex}}=d_{\mathrm{em}}=5 \mathrm{~nm}$. Insert: the reaction kinetics. (b) The probe system was used FL-CO-1 + PdCl $_{2}(0.5 \mu \mathrm{M}$ each), and CORM-3 $(5 \mu \mathrm{M})$ was added. $\lambda_{\mathrm{ex}}=490 \mathrm{~nm}$, slit width: $d_{\mathrm{ex}}=5 \mathrm{~nm}, d_{\mathrm{em}}=10 \mathrm{~nm}$. (c) The probe system was used FL-CO-1 $+\operatorname{PdCl}_{2}(0.1 \mu \mathrm{M}$ each $)$, and CORM-3 $(1 \mu \mathrm{M})$ was added. $\lambda_{\mathrm{ex}}=490 \mathrm{~nm}$, slit width: $d_{\mathrm{ex}}=5 \mathrm{~nm}, d_{\mathrm{em}}=10 \mathrm{~nm}$. (d) The probe system was used FL-CO-1 $+\mathrm{PdCl}_{2}$ $\left(0.05 \mu \mathrm{M}\right.$ each), and CORM-3 $(0.5 \mu \mathrm{M})$ was added. $\lambda_{\mathrm{ex}}=490 \mathrm{~nm}$, slit width: $d_{\mathrm{ex}}=d_{\mathrm{em}}$ $=10 \mathrm{~nm}$.
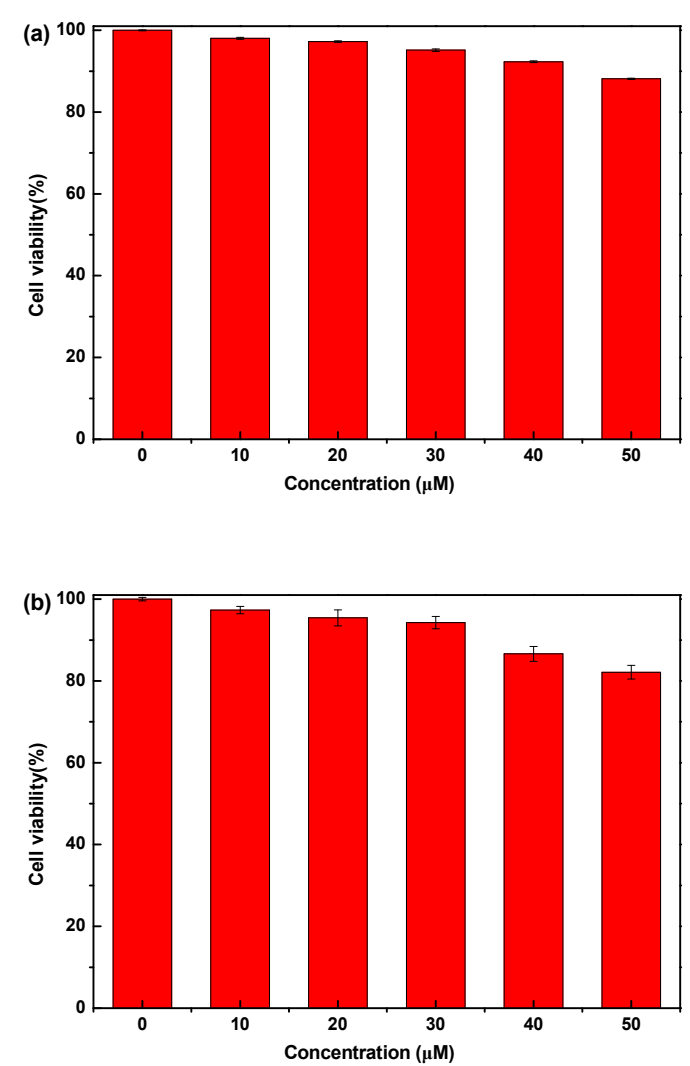

Figure S10. (a) Percentage of viable A549 cells after treatment with different concentrations of probe FL-CO-1 after 24 hours by MTT assay. (b) Percentage of viable A549 cells after treatment with different concentrations of the probe system (FL-CO-1 $\left.+\mathrm{PdCl}_{2}, 1: 1\right)$ after 24 hours by MTT assay. 


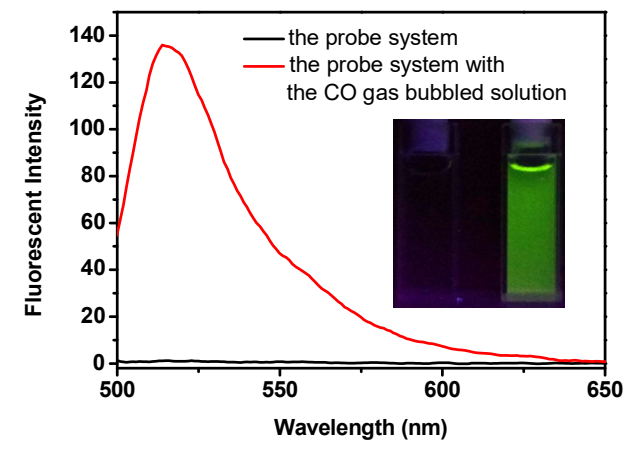

(1)
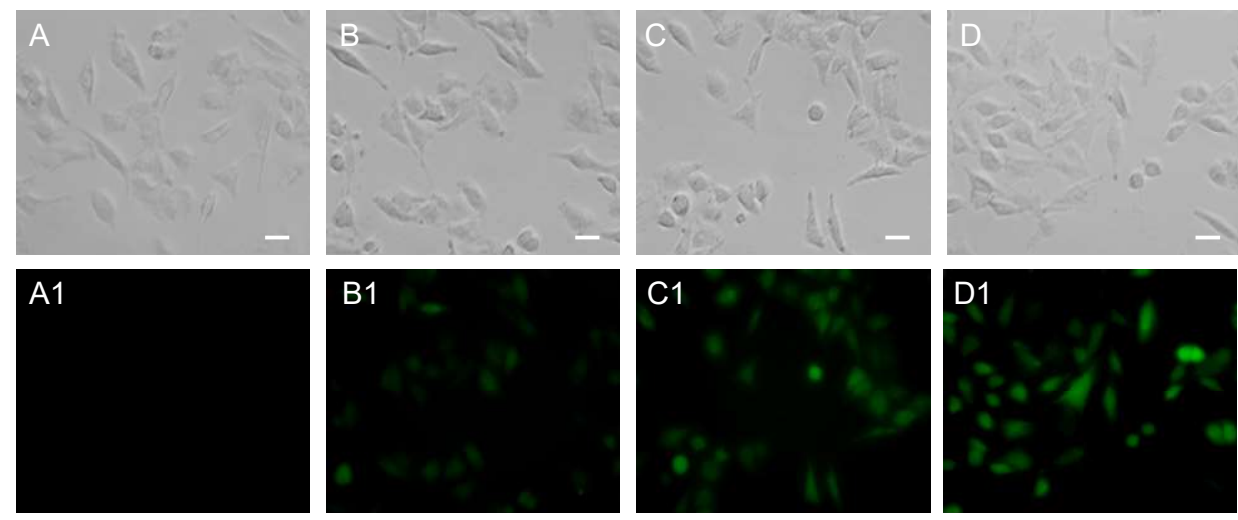

(2)

Figure S11. Detection and cell imaging of CO (the source of CO is from a CO stock solution made by bubbling $\mathrm{CO}$ gas into water) with FL-CO-1 $+\mathrm{PdCl}_{2}$. (1) Fluorescent spectra changes of the probe system (FL-CO-1 $+\mathrm{PdCl}_{2}, 5 \mu \mathrm{M}$ each) upon addition of an estimated $\sim 50 \mu \mathrm{M}$ of $\mathrm{CO}$ gas solution in PBS buffer (10 mM, pH 7.4, with $0.5 \% \mathrm{DMSO}, \mathrm{v} / \mathrm{v}$ ) at $37{ }^{\circ} \mathrm{C}$. The spectra were collected after $15 \mathrm{~min} . \lambda_{\mathrm{ex}}=$ $490 \mathrm{~nm}$, slit width: $d_{\mathrm{ex}}=d_{\mathrm{em}}=2.5 \mathrm{~nm}$. Insert: emission color change observed under a light of $365 \mathrm{~nm}$. (2) Fluorescent imaging of CO in A549 cells by the probe system (FL-CO-1 $+\mathrm{PdCl}_{2}, 1 \mu \mathrm{M}$ each). Top row A-D: bright field images. Bottom row A1-D1: fluorescent images of A-D, respectively, with excitation wavelength at 450-480 nm. A and A1: The cells were incubated with the probe system (FL-CO-1 + $\mathrm{PdCl}_{2}, 1 \mu \mathrm{M}$ each) for 30 min. $\mathrm{B}$ and $\mathrm{B} 1, \mathrm{C}$ and $\mathrm{C} 1$, and $\mathrm{D}$ and $\mathrm{D} 1$ : cells were pre-incubated with an estimated 1,5 and $10 \mu \mathrm{M}$ of $\mathrm{CO}$ gas solution for $30 \mathrm{~min}$, then with the probe system for $30 \mathrm{~min}$, respectively. Scale bar $=20 \mu \mathrm{m}$. 